Sustainability reporting challenges in developing countries: Towards management perceptions research evidence-based practice

\begin{tabular}{|r|l|}
\hline Journal: & Journal of Accounting in Emerging Economies \\
\hline Manuscript ID & JAEE-01-2020-0007.R3 \\
\hline Manuscript Type: & Review Paper \\
\hline Keywords: & $\begin{array}{l}\text { sustainability reporting, developing countries, challenges, managerial } \\
\text { perception-based research, GRI, evidence-based practice }\end{array}$ \\
\hline \multicolumn{2}{|l}{} \\
\hline
\end{tabular}




\title{
Sustainability reporting challenges in developing countries: Towards management perceptions research evidence-based practices
}

\begin{abstract}
Purpose

The purpose of this paper is threefold. First, it aims to identify managerial perceptions-based research determinants of sustainability reporting. Second, it sets out to evaluate the impact of the Global Reporting Initiative (GRI) efforts in increasing SR in developing countries. Third, the researcher argues for the adoption of management perceptions research evidence-based practices (EBP) to address SR challenges in developing countries.
\end{abstract}

\section{Design/Methodology/Approach}

The study was undertaken using a desk-based review of management perceptions-based research literature on the determinants of SR. The impact of GRI efforts in increasing adoption of SR was undertaken through both desk-based research and descriptive analysis of data obtained from the GRI database from 2014 to 2019 relating to 107 developing countries. The call for the adoption of management perceptions research EBP is based on a critical analysis of both the management perceptions of the determinants of SR research and evaluation the impact of GRI efforts to increase SR in developing countries.

\section{Findings}

Training, legislation, issuing of guidance, stakeholder pressure, awareness campaigns, market and public pressure were identified as some of the determinants of SR. The evaluation of the impact of GRI efforts shows they had limited impact on increasing SR in developing countries. Research needed to adopt management perceptions research EBP is identified.

\section{Research limitations/implications}

This study is conceptual. Management perceptions-based research is needed in more developing countries to better understand the determinants of SR and identify the most effective policies or practices to address related challenges.

\section{Originality/Value}

The findings contribute to the calls to make academic research more relevant to policy formulation. In particular, the proposal for research needed to inform EBP adoption to address SR challenges in developing countries is new.

\section{Keywords}

Sustainability reporting, developing countries, challenges, managerial perceptions-based research, GRI, evidence-based practice

\author{
Paper Type \\ Conceptual Paper
}




\section{Introduction}

Research evidence suggests that developing countries continue to lag behind in terms of sustainability reporting. For example, commenting on sustainability reporting trends from 1996 to 2005, Milne and Gray (2007) conclude that sustainability reporting (SR) is very much a 'developed' country phenomenon as incidences of reporting were much lower in developing countries such as China, Egypt, Bangladesh, Kenya and Chile. Although the GRI (2016) notes that there has been a rapid uptake in SR in developing countries, this mostly relates to Asia, with a less significant trend observed in Latin America and the Caribbean, and Africa. However, Wokeck (2019) suggests that large gaps remain as SR uptake is limited to large firms in developing countries while it is slow in many developing countries and least developed countries. The challenges to SR in developing countries include resource constraints and capacity gaps, including lack of strategic direction from management, data gathering, report writing and internal capacity, and the availability of qualified external support and service providers (de Villiers, 2003; Belal and Cooper, 2011; Matta et al., 2019).

Not surprisingly, academic efforts have been made to understand the determinants of SR in developing countries (see Belal and Momin, 2009; Fifka, 2013; Dienes et al., 2016; Hahn and Kuhnen, 2016; Ali et al., 2017). Such research efforts have used either the quantitative approach (Liu and Anbumozhi, 2009; Baje et al., 2020) or the qualitative approach (de Villiers, 2003, Matta et al., 2018). Quantitative studies (henceforth content analysis) undertake content analysis of mostly annual reports to determine the volume and extent of SR (e.g., Khan et al., 2013; Wuttichindanon, 2017; Mudiyanselage, 2018) and use secondary data-based determinants such as company size as a proxy for legitimacy theory. Conversely, qualitative studies (henceforth management perceptions) employ questionnaires and interviews, and directly explore managerial motivation for SR (Belal and Owen, 2007; Joudeh et al., 2018). Similarly, practical efforts have been made, mainly by the Global Reporting Initiative (GRI), to increase SR in developing countries (see Section 3). Despite the academic and practical efforts, though, SR challenges still persist and developing countries continue to lag behind developed countries in terms of SR. Therefore, there is the need for a critical analysis of and suggestions for how both academic research and practice can contribute to effectively address SR challenges in developing countries.

Therefore, the three objectives of this conceptual paper are as follow: (i) to identify managerial perceptions-based research determinants of sustainability reporting (SR); (ii) to evaluate the impact of Global Reporting Initiative (GRI) efforts in increasing SR in developing countries; and (ii) to argue for the adoption of management perceptions research 
evidence-based practices (EBP) to address SR challenges in developing countries. This is achieved by reviewing management perceptions-based research on determinants of SR. We evaluate GRI efforts in increasing SR in developing countries through a review of published information about its work and also through an analysis of the trends in sustainability reports uploaded on its database for a six-year period 2014 to 2019. Our call for a move towards the adoption of management perceptions research EBP is based on a critical analysis of both the academic research on management perceptions of the determinants of SR and from evaluating the impact of GRI efforts to increase SR in developing countries.

We focus our literature review on management perceptions rather than content analysis studies because of their relevance to policy making. For example, one limitation of the content analysis studies is that they contribute more to theory than to practice (see Belal and Momin, 2009; Hahn and Kuhnen, 2013; Dienes et al., 2016; Ali et al., 2017). For instance, Haniffa and Cooke (2005) conclude that their finding of a significant relationship between corporate social disclosure (CSD) and foreign shareholders indicates that Malaysian companies use CSD as a proactive legitimation strategy, consistent with legitimacy theory. Similarly, drawing on legitimacy theory, Khan et al. (2013) suggest that when companies are publicly held, they are expected to become more involved in social activities to ensure organisational legitimacy and disclose more of these activities. Kouloukoui et al. (2019) report that corporate characteristics such as company size, financial performance and country of origin are all significantly associated with climate risk disclosures, and they conclude that their findings are consistent with legitimacy theory. Also, the use by content analysis studies of proxies such as company size for managerial motivations for SR means that they indirectly explain the reasons managers adopt Corporate Social Responsibility (CSR) reporting (Belal and Momin, 2009). As such, content analysis studies-based research evidence many not be appropriate for recommending policy or practices to address SR challenges.

Unlike content analysis studies, managerial perceptions studies provide direct evidence of the motivation for SR. According to de Villiers (1999), the best method for determining someone's motives is asking what these motives are, as any alternative method would of necessity include guesswork. Admittedly, asking someone a question may not always yield an honest response, and there is an element of risk that the true motive is not given, but asking the incumbent remains the most direct approach, as there is no independent source for ascertaining true motive (de Villiers, 1999). As such, managerial perceptionsbased studies can contribute to accounting practice and address a research gap identified by Adams and Larrinaga-Gonzalez (2007) who question the extent to which the quantitative 
research can effect practical changes and suggest that sustainability accounting and reporting research has largely ignored the practice in organisations.

The rationale for evaluation of the impact of Global Reporting Initiative (GRI) efforts in increasing SR in developing countries is because it is the leader in increasing SR worldwide. For example, Brown et al. (2009) indicate that the GRI is arguably the bestknown set of SR guidelines worldwide. Etzion and Ferraro (2010) suggest that the GRIdeveloped SR guidelines have quickly become the de facto standard for meaningful, progressive 'triple-bottom line' (financial, environmental and social) reporting. The success of the GRI is remarkable given that, during the 1990s, many guidelines for SR were produced, including those by the Multinational Enterprise Guidelines of the Organisation for Economic Co-ordination and Development, the International Chamber of Commerce's Business Charters for Sustainable Development, and the United Nations Global Compact. Moreover, guidelines were also developed as part of an environmental management system, such as ISO 14001 and the European Eco-Management and Audit Scheme (EMAS) framework (Etzion and Ferraro, 2010).

The other reason for evaluating efforts by the GRI is because it administers a database on which any organisation around the world can upload its sustainability report. The information on the database now measures each country's progress towards achievement of Sustainable Development Goal (SDG) 12. Target 12.6 'encourages companies, especially large and transnationals, to adopt sustainable practices and integrate sustainability information in their reporting cycle'. The indicator for this target is 12.6 .1 which is the 'number of companies publishing sustainability reports' on the GRI website each calendar year. Thus, through the GRI SDG12.6.1 Tracker, it is possible to determine the increase or decrease in number of companies from each country uploading their sustainability reports on the GRI database over a certain period. For the purpose of this paper, we analyse the trend in the number of organisations from each developing country uploading their sustainability reports from 2014 to 2016. Finally, in 2016, the GRI also published a strategy document (see Section 3) that is specifically on 'increasing and improving SR in developing countries'. Based on the foregoing reasons, we believe the evaluation of the impact of the GRI's work in increasing SR in developing countries is justified.

The findings show that there several management perceptions-based determinants of SR including training, legislation, issuing of guidance, stakeholder pressure, awareness campaigns, market and public pressure. The results of evaluating the impact of GRI efforts to increase SR in 107 developing countries also show that, for the six-year period from 2014 to 
2019, the number of developing countries with at least one organisation uploading its sustainability report on the GRI database decreased from 11 to 10 countries for the Africa region, while in the Asia region, the number of countries rose from 16 to 17 countries, and in the Latin America and the Caribbean region the number of countries similarly rose by 1 from 25 to 26 . These results suggest that the efforts by the GRI had a limited impact in increasing $\mathrm{SR}$ in developing countries. Based on the management perceptions research of the determinants of SR and analysis of the impact of GRI efforts, we argue for the adoption of EBP that will effectively address SR challenges in developing countries and suggest the research agenda needed going forward.

The contributions of this conceptual paper are as follows. The paper contributes to a greater understanding of the determinants of SR by documenting, for the first time, a comprehensive list of management perceptions-based determinants of SR in developing countries. This is because there is no published paper on the literature review of management perceptions of the determinants of SR. The individual studies that exist have focused on the reason for either the presence (de Villiers, 1999, Rahaman, 2004) or the absence (e.g., Mitchell and Hill, 2009; Belal and Cooper, 2011) of SR. According to Bebbington and Unerman (2008), it is important to understand not just what is disclosed but also what is omitted to fully understand corporate motivation behind CSR. Further, the paper contributes to the existing literature by evaluating the impact of the GRI's work in increasing SR in developing countries. Although Brown et al. (2009) and Etzion and Ferraro (2010) evaluated the reasons why the GRI has become the dominant body for developing SR guidelines, there is a dearth of literature on the impact of the GRI's efforts on increasing SR in developing countries. Finally, the paper contributes by advocating for the adoption of management perceptions-based research EBP to address SR challenges in developing countries. This is significant because it is new knowledge and will contribute to SR practice rather than theory. Moreover, it answers calls that have been made for several years to make accounting research more relevant to the real world. For example, Adams and Larringa-Gonzalez (2007) call for research engagement with SR practice.

The rest of the paper is organised as follows. The next section is a literature review on management perceptions of the determinants of SR in developing countries. This is followed by an evaluation of the impact of policies and practices employed by GRI to encourage adoption of SR in developing countries in Section 3. The case for adoption of management perceptions research EBP to address SR challenges is discussed in Section 4. The final section summarises and concludes the study. 


\section{Management perceptions research of the determinants of SR}

Management perceptions-based literature on the determinants of SR either investigates what motivates (e.g., Jaggi and Zhao, 1996; Belal and Owen, 2007; Ismaeel and Zakaria, 2020) the reporting of SR information or constrains it (Mitchell and Hill, 2009; Belal and Cooper, 2011; Hossain et al., 2015). Knowledge of what motivates or prevents management from engaging with SR is relevant for coming up with practices or policy solutions to encouraging SR in developing countries. For example, Adams (2002) suggests that an understanding of the factors which influence disclosure is necessary to improve accountability particularly in the form of quality, quantity and extensiveness; and the completeness or comprehensiveness of reporting (by understanding the reasons for nondisclosure). Solomon and Lewis (2002) also note that understanding the reasons for inadequate disclosure will allow interested parties to develop policies that may alleviate these inadequacies. Therefore, this section discusses management perceptions research results on the determinants of SR adoption and identify what practices or policies these studies recommended to address SR challenges in developing countries.

One of the earliest studies on the constraints to CSR reporting was by Teoh and Thong (1984). Based in Malaysia the findings suggest that the need to keep the annual report brief, no reason to report, and the fact that CSR information is communicated through other channels are some of the reasons why CSR information did not appear in the annual report. Jaggi and Zhao (1996) investigate management attitudes and motivation for environmental disclosures. They report that the management's perception was that a company will have a better image if they disclosed environmental information and that the stakeholders have a right to such information. A study by de Villiers (1999) in South Africa interviewed management from six organisations closely involved in making environmental information disclosure decisions. The main findings of the study are that following competitors, accountability, recognising good employees, commitment to industry standards, informing employees, complying with legal requirements and preventing people from believing in incorrect information supplied by others motivated environmental disclosures. In a study of social and environmental reporting in Ghana, Rahaman (2000) reports that the main motivation for disclosing the information was the pressure to comply with the requirements of funding agencies such as the World Bank.

A study by de Villiers (2003) is one of the most comprehensive articles on the constraints to SR. The study identifies several factors based on questionnaire survey 
responses from 72 companies listed on the Johannesburg Stock Exchange. The results indicate that the most significant constraints relate to "not being a legal requirement to report environmental information' and 'the unavailability of data'. 'No need or motivation to disclose', 'no demand for the information' and 'do not know what/how to report' were ranked third, fourth and fifth respectively, based on the percentage of respondents who regarded the constraint as either 'important' or 'very important'. Other SR constraints regarded as 'important' or 'very important' by over $50 \%$ of the respondents include 'costs exceeding benefits' and 'other disclosure priorities'. The main strength of de Villier's (2003) study is that it not only documents several SR constraints but also provides information on the relative importance of the constraints. However, a possible weakness is that the results are based on a questionnaire which suggested a list of possible environmental reporting constraints to the respondents. This is problematic given that even if a constraint did not apply to the company, the respondent was still forced to rank its importance. It is doubtful that the study would have reported such a long list of SR constraints had respondents been asked to list the constraints by themselves.

In case study on the Volta River Authority (VRA), a public sector organisation in Ghana, Rahaman (2004) reports that the main motivation for social and environmental reporting was pressure to comply with the requirements of funding agencies such as the World Bank. Also on motivation for SR in Bangladesh, Belal and Owen (2007) find that the main motivation was the desire by management to manage powerful stakeholders groups whilst perceived pressure from external forces such as instructions and demands from international buyers was driving the process forward. Another Bangladesh study by Islam and Deegan (2008) also finds evidence of stakeholder pressure as motivating SR. Specifically, the study finds that multinational buying companies, the International Labour Organisation (ILO), UNICEF, US Governments, NGOs and the media impose pressure on the companies to engage with SR.

Mitchell and Hill (2009) report that one of the main constraints to reporting of social and environmental information in South Africa was 'the unavailability of data', stating that the reasons for this ranged from 'data being too difficult to obtain', 'lack of resources' and 'lack of pressure' to 'not being a legal requirement'. Belal and Cooper (2011) interviewed 23 senior corporation managers to investigate the disincentives to SR in Bangladesh. The findings suggest that the main reasons for non-disclosure include 'lack of resources', 'the profit imperative', 'lack of legal requirements', 'lack of knowledge/awareness', 'poor performance' and 'fear of bad publicity'. In terms of lack of knowledge or awareness, Belal 
and Cooper (2011) suggest that CSR was relatively new to companies in developing countries and, as a result, many respondents were not familiar with the requirements. This was confirmed by most of their interviewees who stated that some of the reasons for nondisclosure might be due to lack of awareness and knowledge regarding CSR amongst corporate managers. The main strength of this paper is that the CSR constraints are identified through in-depth interviews rather than by suggesting possible SR constraints to the interviewees.

Momin and Parker (2013) investigate the factors that constrain SR among multinational corporations' subsidiaries. From interviews with 39 individuals, the factors identified as CSR reporting constraints include informal beliefs and norms (not viewed favourably by investors or other targeted groups); very low expectations (no demand for CSR); lax reporting regulations (no requirement to report information), and low level of implementing law (no enforcement of laws, so no one cares even if it was a requirement). Although this study is limited to subsidiaries of MNCs, and hence it could be argued that the results cannot be generalised, some of the SR constraints - such as 'no legal requirements' and 'no demand for information' - are the same as those documented in studies not based on subsidiary companies (e.g., de Villiers, 2003).

Hossain et al. (2015) conducted semi-structured interviews with 25 managers from the top 100 companies listed on the Dhaka Stock Exchange. The interview data were matched with disclosures provided by the organisations in their annual reports or other stand-alone sustainability reports. The findings suggest that the interviewees regarded lack of regulatory framework along with socio-cultural and religious factors as contributing to low levels of disclosure. According to Hossain et al. (2015) religious beliefs are a constraint in CSR disclosures because there is a belief in Islam that individuals are accountable to God and should not publicly disclose their good deeds through the annual report. This is noteworthy because most existing literature assumes that managers around the world use CSR for corporate legitimation. Zhao and Patten (2016) sought to determine the perceptions of 14 managers from nine different state-owned enterprises in China regarding motivations for social and environmental accounting. Their results indicate that peer institutions' pressure, image enhancement and public pressure motivate such disclosures.

Nwobu et al. (2018) surveyed 54 managers in Nigeria to determine their views on 25 motivations for SR. The results indicate that the main motivations based on the average ranking on a five-point Likert scale include initiation by Chief Executive Officer, employee training, investors' concern, Central Bank sustainability banking principles, foreign lenders' 
pressure and Securities and Exchange Commission Code of Corporate Governance. A study by Matta et al. (2019) carried out in India compares the managers' perceptions of factors driving disclosure and those affecting non-disclosure of firms that did not report and those that did report environmental information. The findings indicate that managers of nonreporting firms had higher average ratings of environmental reporting constraints such as 'to avoid providing sensitive and confidential information to competitors' and 'no legal requirement/obligation to report' compared to managers of the reporting firms. In terms of factors motivating environmental disclosures, Matta et al. (2019) find that reporting firms generally had higher mean ratings for the main factors such as 'compliance with local laws and regulations', 'long-term survival of the organisation' and 'improving corporate image'. The study by Ismaeel and Zakaria (2020) is unusual because it covers seven countries (Oman, Kuwait, the UAE, Lebanon, Qatar, Palestine and Bahrain) in its investigation of the motivation for SR. The study finds that transparency, improve CSR/sustainability performance, stakeholder' right to know, spreading culture of CSR and accountability are the main factors motivating SR. However, the main limitation of the study is that it is based on interviews with one manager from each of the seven countries.

Table 1 summarises the studies on managerial perceptions of the determinants of SR discussed above. The summary also shows that the 16 studies have covered one country except for that of Ismaeel and Zakaria (2020) which covered seven countries. Except for Jaggi and Zhao (1996) and Matta et al. (2019) who used questionnaire surveys, the rest of the studies used personal interviews.

\section{[INSERT TABLE 1 ABOUT HERE]}

The results in Table 1 also show that the sample sizes upon which the studies are based are very small. For example, Ismaeel and Zakaria (2020) use a sample size of seven managers, while the study with the largest sample is that by Teoh and Thong (1984) who interviewed 100 managers. This is not surprising given that it is time-consuming to interview individuals or obtain high response rates from questionnaire surveys compared with analysing publicly available data such as those contained in the annual reports.

Despite their small sample sizes, some managerial perceptions studies of the determinants have recommended policies and practices that could be adopted to address SR challenges in developing countries based on the findings. For example, to encourage adoption of SR given that the absence of legal requirements is perceived as a constraint, de Villiers 
(2003), Mitchell and Hill (2009) and Matta et al. (2019) have all suggested that making it a legal requirement for companies to produce sustainability reports could resolve the problem. However, there are doubts about whether legislation will be effective due to lack of enforcement in developing countries. For example, Belal and Cooper (2011, p. 663) assert that:

Formal regulation could legally require companies operating in Bangladesh to publish CSR reports generally and more specifically to disclose on relevant eco-justice issues such as child labour, poverty alleviation and equal opportunities. In the absence of effective legal enforcement mechanisms, however, it is doubtful to what extent formal regulations will be helpful in this regard.

According to Hossain et al. (2015), an alternative policy solution to making it a legal requirement for companies to produce sustainability reports is for the countries' governments to develop guidance on how companies should produce sustainability reports. The issue of guidance is likely to address SR challenges by increasing both the number of companies reporting and the quality of reporting based on empirical evidence. For example, Tauringana and Chithambo (2015) report that the publication of guidance by the Department for Environment, Food and Rural Affairs (DEFRA) had a significant effect on disclosing greenhouse gas (GHG) emissions in the UK. Mitchell and Hill (2009) suggest that a possible policy solution to the constraint of not engaging in SR because costs exceed benefits is legislation, and public and market pressure.

Regarding lack of expertise identified as a constraint to adopting SR by de Villiers (2003), Mitchell and Hill (2009), Belal and Cooper (2011) and Matta et al. (2019), training has been suggested as a policy solution. According to Belal and Cooper (2011, p. 664):

It is true that corporate managers in developing countries need necessary training to achieve the required skills and knowledge to be able to embark on CSR reporting activities, which would require commitment of additional resources that might be lacking, particularly domestic companies, as suggested by the interviewees.

Nwobu et al. (2018) also recommend training as an appropriate practice to encourage the adoption of SR; they suggest that companies need to take a positive stance on employee training pertaining to sustainability reporting to improve their engagement in SR. Finally, Mitchell and Hill (2009) recommend legislation and public or market pressure to force company management who see no need to or have no motivation to disclose CSR information. Since the GRI is the main organisation leading efforts to increase SR in 
developing countries, the next section evaluates the impact of its effort in increasing SR in developing countries. This is particularly so given that most practices and policies that the GRI uses are recommended by management perceptions research on determinants of SR discussed in this section.

\section{Impact of GRI policies and practices on SR adoption}

\subsection{Strategy and achievements}

In this section we discuss GRI strategy in increasing and improving SR in developing countries. We also discuss some of the achievements mostly based on literature published by the GRI in standalone publications and on its website.

According to the GRI (2016) one of its strategic objectives is about 'increasing and improving sustainability reporting in developing countries'. According to the GRI (2016, p. 17):

Activities under this objective will work towards making reporting relevant for all stakeholders (developing countries), including those stakeholders who are 'underserved' or not traditionally reached, such as small and medium-sized enterprises (SMEs), local community leaders and advocacy groups. It will strengthen the capacity and expand the base for report makers and users.

Under strategic objective (2) (GRI, 2016, p. 19), the GRI indicates that several activities will underpin the execution of this objective. For example, the GRI will expand and improve the use of GRI standards in developing countries. The GRI will also implement the joint United Nations Global Compact (UNGC), World Business Council for Sustainable Development (WBCSD) and GRI project, the SDG Compass, providing a reporting toolkit for businesses to measure their contribution to the SDGs. Further, under this strategy, the GRI will seek to equip small- and medium-sized enterprises (SMEs) with the ability to become involved in SR in developing countries. There will also be training and capacity building for better-quality reporting and the promotion of supply chain transparency. The GRI will empower users of data by activating civil society, media, investors, employees and governments to fully benefit from the reporting process and harmonisation of standards. The strategy will see the development of creative communications around the GRI's work and help corporate actors and reporters to package and communicate their sustainability information to stakeholders.

Table 2 summarises of the policies and practical actions that the GRI has taken to increase SR in developing countries. For example, to expand and improve the use of SR 
standards, the GRI has not only developed and published SR standards but has also persuaded several stock exchanges such as the Johannesburg Stock Exchange, Indonesia Stock Exchange, Securities and Exchange Board in India, Bursa Malaysia and the Nigerian Stock Exchange to use SR standards as a baseline for businesses to be listed. The GRI has also taken steps to implement the SDG compass such as developing and running courses through its network of partners around the world on how to integrate SDGs in SR.

\section{[INSERT TABLE 2 ABOUT HERE]}

Through the Competitive Business Program, the GRI has assisted SMEs in developing countries such as Colombia, Ghana, Indonesia, Peru, South Africa and Vietnam to produce sustainability reports for the first time through training and mentorship. The mentorship programme, GRI standards examination and the tailored workshop are the main means through which the GRI achieves its training and capacity building for a quality reporting programme. To promote supply chain transparency, the GRI has developed an elearning module which covers current practices in reporting on the supply chain among other issues. To make sure that the SR data are used, the GRI continuously improves its SR standards to ensure that such standards continue to be relevant for the needs of the users. For example, since 2016, the GRI has developed a new standard under 'economic topics' on taxation (GRI 207, effective January 2021), and revised GR1 303 - Waste and Effluents, GRI 306 - Waste and GRI 403- Occupational Health and Safety. Finally, to improve the ability of SMEs to communicate, the GRI Digital Reporting Platform enables SMEs to package and communicate sustainability information.

Overall, the work of the GRI aimed at increasing SR is mostly achieved through training although there are many elements involved. Training is about making sure that organisation staff can apply the SR standards to produce sustainability reports. Although the GRI runs its own training, most of the training now is carried out by partners who are 'certified' to run their own training courses in different countries around the world. Training is also delivered through tailored workshops, the Competitive Business Program, and the Elearning course. However, the GRI charges to cover its training costs so the training is not easily affordable to many organisations in developing countries. Besides the training, the GRI also tries to improve SR in developing countries through developing guidance in the form of SR standards and persuading stock exchanges to require companies seeking listing to use the standards for preparing sustainability reports. The GRI also uses awareness campaigns to 
inform stakeholders of the benefits of SR; for example, the GRI (2016) makes a case for the casual link between sustainability reporting and sustainable development. Similarly, the GRI (2017) shows how corporate reporting can help end poverty. In a research document aimed at persuading stakeholders to apply pressure on organisations to engage with SR, the GRI (2015) documents how civic society, investors, businesses, government and market regulators and the media can all use SR data to inform their decisions and drive change.

\subsection{Has SR increased in developing countries?}

Despite all the efforts of the GRI to increase SR in developing countries, as explained above, the impact of its efforts is ultimately judged based on the increase in number of countries and of organisations from each country that upload their sustainability reports on the GRI database in accordance with SDG 12.6.1 as discussed before. As a result, this section is dedicated to evaluating the impact of the GRI efforts in increasing SR in developing countries. To do this we identified all 107 developing countries by reference to the United Nations (2019) World Economic Prospects which divides developing countries into regions of Africa (51 countries), Asia (32 countries) and Latin America and the Caribbean (24 countries). During March 2020, we then searched the GRI database recording the number of organisations that uploaded their sustainability reports for each of the six calendar years from 2014 to 2019. We chose 2014 as our start date because SDG 12.6.1 was adopted in September 2015, so we wanted to start the analysis before the SDG was adopted, and 2019 was the last full calendar year available.

The results of the analysis are presented in Table 3 and show the three regions of Africa (Panel A), Asia (Panel B) and Latin America and the Caribbean (Panel C) and the respective countries. The results show the number of organisations for each calendar year (2014 to 2019) from each country uploading sustainability reports on the GRI database. The last column in the table shows the increase for each country as the difference (+/-) between number of organisations uploading their sustainability reports in 2019 compared to 2014 for each country. For the Africa region, very few countries are uploading their sustainability reports over that period. For example, in North Africa only organisations in Egypt and Morocco have uploaded their sustainability reports. For Central Africa, no country has any organisation uploading its sustainability report and in East Africa only Kenya and Uganda have organisations uploading some sustainability reports in 2019. While most countries in Southern Africa have had companies uploading sustainability reports over the six-year period, what is worrying is that only four out of ten countries have organisations uploading 
reports in 2019. West African countries also appear not to engage with SR as indicated by the fact that organisations from only two out of 15 countries filed their sustainability reports in 2019.

Compared to the Africa region, Asia seems to engage more with SR. For example, in the East Asia region, only Brunei Darussalam has had no organisation uploading its report on the GRI database between 2014 and 2019, and in 2019, 11 out of the 13 countries had organisations uploading their sustainability reports. In terms of the individual countries in East Asia, Taiwan recorded the biggest increase over the six years with 296 more organisations in 2019 uploading their reports compared to the case in 2014. Of the six countries in South Asia, only Nepal has had no organisation uploading its sustainability report from 2014 to 2019. Also, over the six years, only Bangladesh and Pakistan experienced a decrease in the number of organisations uploading their sustainability reports. The West Asia region has 11 out of the 13 countries have organisations uploading their sustainability reports on GRI database in 2019. However, usually the numbers are mostly in single digit figures such as those for Bahrain, Jordan, Kuwait, Lebanon, Oman, Qatar and Saudi Arabia.

The Latin America and the Caribbean regions show a mixed picture with the Caribbean region not so engaged with SR compared to the Mexico and Central America and South America regions. For example, over the six years, among the seven Caribbean countries, only the Dominican Republic has had an organisation uploading its sustainability report on the GRI website. Regarding the Mexico and Central America region, over the sixyear period, all countries had organisations uploading their sustainability reports on the GRI database once although no organisation uploaded its sustainability report from El Salvador in 2019. There was also a drop by 19 in terms of the number of organisations from Mexico putting their sustainability reports on the GRI database. All 10 South America countries had organisations uploading their sustainability reports on the GRI database for each of the six years under review. Peru has experienced a rise of 224 in terms of number of organisations filing the reports with GRI while Brazil, Chile and Colombia have all experienced decreases in 2019 compared to 2014.

Table 4 shows the overall picture in terms of the number of developing countries that experienced no change, decrease or increase in the number of organisations uploading their sustainability reports on the GRI website from 2014 to 2019. On average, the Africa region shows that $17.65 \%$ of the countries experienced a decrease in the number of organisations uploading their sustainability reports in 2019 compared with 2014 . However, $11.76 \%$ of the 
countries saw an increase in the number of organisations uploading the sustainability reports over the same period. The statistics in Table 4 also show that $70.59 \%$ of the countries experienced no change in the number of organisations uploading their sustainability reports on the GRI database between 2014 and 2019. This is because most countries had no organisation uploading its sustainability report in 2014 and that remained the case until 2019. The situation in Asia is much better as, on average, only $18.75 \%$ of the countries experienced no change while $43.75 \%$ experienced a decrease and $37.5 \%$ an increase in the number of organisations uploading the sustainability reports on the GRI database. However, the fact that the percentage decrease is more than the percentage increase suggests a downward trajectory in terms of engagement with SR. Similarly, in Latin America and the Caribbean, the analysis shows that $25 \%$ of the countries experienced no change while $41.66 \%$ experienced a decrease and $33.33 \%$ an increase in the number of organisations uploading sustainability reports on the GRI database during the period 2014 to 2019.

Based on the preceding analysis it is evident that, overall, the SR in developing countries has not increased as expected. This is despite the efforts by the GRI to increase SR in developing countries. The fact that the GRI employs the policies and practices such as training, producing guidance in terms of Global Sustainability Reporting Standards, awareness campaigns, and sensitising stakeholders identified by the management perceptions research on the determinants of SR suggests that there is an urgent need to identify which of these recommended practices and policy solutions are more effective in addressing SR challenges in developing countries based on research evidence. As a result, the following section puts forward the case for adopting research management perceptions research EBP to address the SR challenges in developing countries.

\section{Towards management perceptions research evidence-based practices}

Evidence-based practice (EBP) in behavioural and social sciences developed out of the evidence-based movement in medicine, which aims to inculcate in clinicians the conscientious, explicit and judicious use of current best evidence in making decisions about the care of individual patients (Sackett et al., 1996, Paynter, 2009). In healthcare, EBP is not only about using the best research evidence in decision making, but also using experience, skills and training that one has accrued as a health professional to consider and understand the patient's situation and values - for instance, available support and financial situation and the practice context such as limited funding (Hoffman et al., 2013). Using research EBP is common in fields such as medicine, nursing, teaching and social work and there are 
advocates for its wider application (Baker, 1984; Hammersley, 2005; Veeramah, 2016). For example, Hammersley (2005) suggests that the idea that policymaking and practice should be evidence-based has become widely accepted as few people would trust a policy or practice that is not based on evidence. The rationale for adoption of EBP generally is articulated by Chalmers (2003, pp. 23-34) who explains that:

Individual policy makers and practitioners are often certain about things that are a matter of opinion. But surveys of practice reveal that these individual certainties often manifested in a very wide range of practices, not infrequently providing indirect evidence of mutual incompatible opinions. This evidence of collective uncertainty about the effects of policies and practices should prompt professionals and the public to find out which opinions are likely to be correct. A lack of empirical evidence supporting opinions does not mean that all the opinions are wrong or that, for the time being, policy and practice should not be based on people's best guesses. On matters of public importance, however, it should prompt efforts to obtain relevant evidence through evaluative research to help adjudicate among conflicting opinions.

Since addressing SR challenges is a matter of public importance due to its positive impact on wider sustainable development and even poverty alleviation in the economic, environmental and social arenas (GRI, 2008), there is a good case for adopting EBP to address SR in developing countries. Adoption of management perceptions research EBP will bring numerous advantages to organisations such as the GRI; these include making it easier to justify its work, secure funding and bolster credibility. Primarily it will remove the guesswork when planning the adoption of new practices - knowing that they work. Therefore, we advocate for the adoption of management perceptions research EBP to address the SR challenges in developing countries. To achieve this, we suggest the following areas of research: (1) More research on management perceptions of the determinants of SR in other developing countries and (2) Independent research on the effectiveness of practices and policies used in addressing SR challenges.

\section{(1) Research on management perceptions of the determinants of SR in more countries}

Our literature review on the research focusing on management perceptions of the determinants of SR in developing countries suggests that such research is limited. This is particularly the case when compared to studies that used the quantitative approach to indirectly document the determinants of SR. For example, Belal and Momin (2009) identified 31 quantitative studies in developing countries compared with six studies on managerial perceptions. Further, the literature review by Ali et al. (2017) documents 29 studies 
quantitative studies as opposed to only seven based on managerial perceptions. In terms of developing country coverage, only three countries (Bangladesh, South Africa and Ghana) have been investigated two or more times. A further 11 countries (Hong Kong, Nigeria, Malaysia, China, Oman, Kuwait, the UAE, Lebanon, Qatar, Palestine and Bahrain) have only one study each. Out of the 107 developed countries, management perceptions of the determinants of SR have only been investigated in 14 countries leaving 93 countries from which there is no knowledge of what management perceives as determinants of SR. Therefore, there is a need for more management perceptions-based research to document more SR determinants and come up with other possible practices of policy solutions to address SR challenges in developing countries. Researchers could therefore address the following research question:

RQ1. What is the nature of management perceptions of SR determinants in different developing countries?

\section{(2) Significance of and differences in determinants based on type of SR}

There is a need to understand the significance of the SR determinants identified. For example, Mitchell and Hill (2009) and Belal and Cooper (2011) find that several determinants accounted for the absence of CSR information, including lack of resources, lack of legal requirements, lack of knowledge/awareness, and fear of bad publicity. However, the relative influence of each determinant is not clear. It is important to understand the relative influence of each SR determinant to prioritise policy recommendations. Further, it is also important to understand whether SR determinants are the same for the reporting of three types of SR information (economic, environmental and social). Existing managerial perceptions-based research has focused on SR determinants relating to CSR (e.g., Mitchel and Hill, 2009; Momin and Parker, 2013), environmental reporting (e.g., de Villiers 2003), or social reporting (Belal and Cooper, 2011). Knowing whether SR determinants are common to all three types of SR information would help in recommending policy. Based on the preceding discussion, future research needs to address the following key research questions:

RQ2. What is the relative influence of the different SR determinants?

RQ3. Do determinants differ based on the type of SR information such as economic, environmental or social?

(3) Research on effectiveness of practices and policies used in addressing SR challenges 
While management perceptions can indicate which practices or policies would most encourage the adoption of SR, there is still a need for independent investigation on the effect of each practice or policy, particularly when using quantitative research techniques in addressing SR challenges. For example, despite the GRI using many policies and practices to increase SR in developing countries such as training, development of guidance, awareness campaigns, and stakeholder pressure, there is no evidence as to which policy or practice is more effective. Therefore, future research needs to evaluate the effectiveness of policies or practices that are either currently employed or those that may be recommended in the future to address SR challenges. To determine the effectiveness of policies such as training or awareness campaigns, it is important to consider whether companies produce sustainability reports beyond initial adoption. For instance, the GRI's Business Competitive Program offering assistance to SMEs to produce sustainability reports is due to end in 2020. While this has been a success in terms of helping the companies to produce their first sustainability reports and upload them on the GRI database, a better criterion against which to judge the effectiveness of the training and assistance would be whether the SMEs will continue to produce the sustainability reports after the programme is finished. The following question should be addressed to fill this research gap and facilitate the adoption of EBP:

RQ4. Which practices or policies are most effective in addressing SR in developing countries, and why?

\section{Summary and Conclusion}

This paper set out identify managerial perceptions-based research determinants of sustainability reporting. In addition, it evaluated the impact of the efforts by GRI to increase SR in developing countries. The final objective was to argue the case for adoption of management perceptions research evidence-based practice (EBP) in addressing SR challenges in developing countries. The results show that among the determinants of SR in developing countries are legislation, training, issuing of guidance, awareness campaigns, and market, stakeholder and public pressure. The evaluation of the impact of GRI efforts to increase SR in developing countries for the six-year period from 2014 to 2019 shows a limited impact. Consequently, we argue for a move towards the adoption of management perceptions research EBP that will increase effectively address SR challenges in developing countries. The paper identified the need for (i) more research on the determinants of SR in other developing countries not covered by existing management perceptions research, (ii) investigation of the significance and differences of determinants based on type of SR, and 
(iii) more research on the effectiveness of practices and policies used in addressing SR challenges.

Despite the limitations of this article as a conceptual paper, this paper has policy implications in terms of addressing SR challenges in developing countries. This is because it documented several practices and policy solutions that could increase SR. By evaluating the impact of the efforts by the GRI, the paper showed that some practices and policy solutions documented by management perceptions studies have so far had limited impact, and identified further research needed to adopt EBP. Adoption of EBP would address SR challenges in developing countries, enabling them to catch up with developed countries. Overall, the paper demonstrated how academic research can inform practice. This answers the calls by by Adams (2002) and Adams and Larringa-Gonzalez (2007) to engage in research that would improve sustainability accounting practice.

\section{References}

Adams C.A. (2002), "Internal organisational factors influencing corporate social and ethical reporting: Beyond current theorising", Accounting, Auditing \& Accountability Journal, Vol. 15 No. 2, pp. 223-250.

Adams, C.A. and Larrinaga-González, C. (2007), "Engaging with organisations in pursuit of improved sustainability accounting and performance", Accounting, Auditing \& Accountability Journal, Vol. 20 No. 3, pp. 333-355.

Adams, C.A., Coutts, A. and Harte, G. (1995), "Corporate equal opportunities (non-) Disclosure", The British Accounting Review, Vol. 27 No. 2, pp.87-108.

Ali, W., Frynas, J.G. and Mahmood, Z. (2017), "Determinants of corporate social responsibility (CSR) disclosure in developed and developing countries: A literature review", Corporate Social Responsibility and Environmental Management, Vol. 24, pp. 273-294.

Baker, E.L. (1984), “Can educational research inform educational practice? Yes!”, The Phi Delta Kappan, Vol. 65 No.7, pp. 453-455.

Bebbington J, and Unerman J. (2008), "Editorial”, Social and Environmental Accountability Journal, Vol. 28 No. 1, pp. 1-2.

Belal, A. R. and Cooper, S. (2011), "The absence of corporate social responsibility reporting in Bangladesh", Critical Perspectives on Accounting, Vol 22. No. 7, pp. 654-667.

Belal, A.R. and Owen, D. (2007), "The views of corporate managers on the current state of, and future prospects for, social reporting in Bangladesh: an engagement-based study", Accounting, Auditing and Accountability Journal, Vol. 20 No. 3, pp. 472-94.

Belal, A.R. and Momin, M. (2009), "Corporate social reporting (CSR) in emerging economies: A review and future direction", Research in Accounting in Emerging Economies, Vol. 9, pp. 119-143.

Brown, H.S., De Jong, M. and Lessidrenska, T. (2009), "The rise of the Global Reporting Initiative: A case of institutional entrepreneurship", Environmental Politics, Vol. 18 No. 2, pp. 182-200. 
Chalmers, I. (2003), "Trying to do more good than harm in policy and practice: The role of rigorous, transparent, up-to-date evaluations", Annals of American Academy of Political and Social Science, Vol. 589, pp.22-40

Deegan, C., and Rankin, M. (1999). The environmental reporting expectation gap: Australian evidence. British Accounting Review, Vol. 31 No. 3, pp. 313-346.

De Villiers, C.J. (1999), “The decision by management to disclose environmental information: A research note based on interviews", Meditari Accountancy Research, Vol. 7, pp. 33-48.

De Villiers, C.J. (2003), "Why do South African companies not report more environmental information when managers are so positive about this kind of reporting?" Meditari Accountancy Research, Vol. 11 No. 1, pp. 11-23.

Dienes, D., Sassen, R. and Fischer, J. (2016), "What are the drivers of sustainability reporting? A systematic review", Sustainability Accounting, Management and Policy Journal, Vol. 7 No. 2, pp. 154-189.

Etzion, D. and Ferraro, F. (2010), "The role of analogy in the institutionalization of sustainability reporting”, Organization Science, Vol, 21 No. 5, pp. 1092-1107.

Fifka, M.S. (2013), "Corporate responsibility reporting and its determinants in comparative perspective - a review of the empirical literature and a meta-analysis", Business Strategy and the Environment, Vol. 22 No. 1, pp. 1-35.

Global Reporting Initiative (2008), Reaching out to developing countries, mid-term review, GRI, Amsterdam.

Global Reporting Initiative (2015), Informing decisions, driving change: The role of data in a sustainable future, GRI, Amsterdam.

Global Reporting Initiative (2016), GRI's contribution to sustainable development, GRI, Amsterdam.

Global Reporting Initiative (2017), Can corporate reporting help end poverty? GRI, Amsterdam.

Hahn, R. and Kuhnen, M. (2016), "Determinants of sustainability reporting: a review of results, trends, theory, and opportunities in expanding field of research", Journal of Cleaner Production, Vol. 59, pp. 5-21.

Hammersley, M. (2005), "Is the evidence-based practice movement doing more good than harm? Reflections on Iain Chalmers' case for research-based policy making and practice", Evidence \& Policy, Vol. 1 No.1, pp. 85-100.

Haniffa RM, Cooke TE. 2005, "The impact of culture and governance on corporate social Reporting”, Journal of Accounting \& Public Policy, Vol. 24 No. 5, pp. 391-430.

Hoffman, T., Bennett, S., \& Del Mar, C. (2013), Evidence-based practice: across the health professions (2nd ed.). Chatswood, NSW: Elsevier.

Hossain, M.M., Alam, M., Islam, M.A. and Hecimovic, A. (2015), "Do stakeholders or social obligations drive corporate social and environmental responsibility reporting? managerial views from a developing country", Qualitative Research in Accounting \& Management, Vol. 12 No. 3, pp. 287-314.

Ismaeel, M. and Zakaria, Z. (2020), "Perception of preparers of sustainability reports in the Middle East", Meditari Accountancy Research, Vol. 28 No. 1, pp. 89-116.

Islam, M.A. and Deegan, C. (2008), "Motivations for an organisation within a developing country to report social responsibility information: Evidence from Bangladesh", Accounting, Auditing and Accountability Journal, Vol. 21 No.6, pp. 850-874

Jaggi, B. and Zhao, R. (1996), "Environmental performance and reporting: Perceptions of managers and accounting professionals in Hong Kong", The International Journal of Accounting, Vol. 31 No. 3, pp. 333-346.

Khan, A., Muttakin, M.B. and Siddiqui, J. (2013), "Corporate governance and corporate 
social responsibility disclosures: evidence from an emerging economy", Journal of Business Ethics, Vol. 114, pp. 207-223.

Matta, R., Akhter, J and Malarvizhi, P. (2019). Managers' perception of factors impacting environmental disclosure' Journal of management, Vol. 6 Iss. 2, pp. 219-229.

Milne, M.J. and Gray, R. (2007), "Future prospects for corporate sustainability reporting", in Unerman, J., O’Dwyer, B. and Bebbington, J. (Eds.), Sustainability accounting and accountability, Routledge, London.

Mitchell, C.G. and Hill, T. (2009), "Corporate social and environmental reporting and the impact of internal environmental policy in South Africa", Corporate Social Responsibility and Environmental Management, Vol. 16, pp. 48-60.

Momin, M.A. and Parker, L.D. (2013), "Motivations for corporate social responsibility reporting by MNC subsidiaries in an emerging country: The case of Bangladesh", British Accounting Review, Vol. 45 Iss. 3, pp. 215-228.

Nwobu, O.A., Iyoha, F. and Owolabi, A. (2018), "Managerial perceptions of corporate sustainability reporting determinants in Nigeria', Journal of Business and Retail Management Research, Vol. 12 No. 2, pp. 72-82.

Paynter, R.A. (2009), "Evidence-based research in the applied social sciences", Reference Services Review, Vol. 37 No. 4, 435-450.

Rahaman, A.S. (2000), "Senior management perceptions of social and environmental reporting in Ghana", Social and Environmental Accountability Journal, Vol. 20 No. 1, pp. 7-10.

Rahaman, A.S., Lawrence, S. and Roper, J. (2004), "Social and environmental reporting at the VRA: Institutionalised legitimacy or legitimation crisis?" Critical Perspectives on Accounting, Vol. 15 No. 1, pp. 35-56.

Sackett, D.L., Rosenburg, W.M.C., Gray, J.A.M., Haynes, R.B. and Richardson W.S. (1996), "Evidence based medicine: what it is and what it isn't: it's about integrating individual clinical expertise and the best external evidence", The British Medical Journal, Vol. 312, pp. 71-72.

Solomon, A. and Lewis, L. (2002), "Incentives and disincentives for corporate environmental Disclosure", Business Strategy and the Environment, Vol. 11, pp. 154-169.

Tauringana, V., \& Chithambo, L. (2015) The effect of DEFRA guidance on greenhouse gas disclosure. The British Accounting Review, Vol. 47, Iss. 4, pp. 425-444.

Teoh H.Y and Thong, G. (1984). "Another look at corporate social responsibility and reporting: an empirical study in a developing country", Accounting Organizations and Society, Vol. 9 No. 2, pp.189-206.

United Nations (2019), World Economic Prospects, https://www.un.org/development/desa/dpad/wp-content/uploads/sites/45/WESP2019 BOOK-ANNEX-en.pdf (accessed 01/06/2020)/

Veeramah, V. (2016), "Using an evidence base to inform practice”, Nursing Times, Vol. 112, Iss. 14 , pp. 20-21.

Wokeck, L. (2019), Corporate sustainability reporting in least developed countries: Challenges and opportunities for action, Occasional Policy Paper Series on The Least Developed Countries, No. 6, UN-OHRLLS.

Zhao, N. and Patten, D.M. (2016), "An exploratory analysis of managerial perceptions of social and environmental reporting in China", Sustainability Accounting, Management and Policy Journal, Vol. 7 No. 1, pp. 80-98. 


\begin{tabular}{|c|c|c|c|c|c|}
\hline & & Rece & & & nion \\
\hline 1 & $\begin{array}{l}\text { Belal and Owen } \\
(2007)\end{array}$ & $\begin{array}{l}\text { Semi-structured } \\
\text { interviews }\end{array}$ & 23 senior managers & $\begin{array}{l}\text { To manage powerful stakeholders, pressure from } \\
\text { external forces (parent companies' instructions } \\
\text { and demands from international buyers). }\end{array}$ & Bangladesh \\
\hline 2 & $\begin{array}{l}\text { Belal and Cooper } \\
(2011)\end{array}$ & $\begin{array}{l}\text { Semi-structured } \\
\text { interviews }\end{array}$ & $\begin{array}{l}23 \text { senior corporate } \\
\text { managers }\end{array}$ & $\begin{array}{l}\text { Lack of resources, profit imperative, lack of legal } \\
\text { requirements, lack of knowledge/awareness, } \\
\text { poor performance, fear of bad publicity. }\end{array}$ & Bangladesh \\
\hline 3 & de Villiers (1999) & Interviews & $\begin{array}{l}6 \text { individuals responsible } \\
\text { for environmental } \\
\text { disclosures }\end{array}$ & $\begin{array}{l}\text { Following competitors, accountability, } \\
\text { recognising good employees, committed to } \\
\text { industry standards, inform employees, comply } \\
\text { with legal requirements, prevent people } \\
\text { believing in incorrect information supplied by } \\
\text { others. }\end{array}$ & South Africa \\
\hline 4 & de Villiers (2003) & Questionnaire survey & 72 companies & $\begin{array}{l}\text { No legal requirement, data not available, no } \\
\text { motivation to disclose, not applicable to industry, } \\
\text { no demand for information, costs exceed benefits, } \\
\text { other disclosure, do not know how/what to report, } \\
\text { others not doing it. }\end{array}$ & South Africa \\
\hline 5 & $\begin{array}{l}\text { Hossain, Alam, } \\
\text { Islam and } \\
\text { Hecimovic }(2015)\end{array}$ & $\begin{array}{l}\text { Semi-structured } \\
\text { interviews }\end{array}$ & 25 senior managers & $\begin{array}{l}\text { Lack of regulatory framework, accountability to } \\
\text { stakeholders (public, community), socio-cultural } \\
\text { (trust) and religious factors (belief that an } \\
\text { individual is accountable to God). }\end{array}$ & Bangladesh \\
\hline 6 & $\begin{array}{l}\text { Islam and Deegan } \\
(2008)\end{array}$ & In-depth interviews & 12 senior officials & $\begin{array}{l}\text { Stakeholder pressure (multinational buying } \\
\text { companies, ILO, UNICEF, US Governments, } \\
\text { NGOs and the media) }\end{array}$ & Bangladesh \\
\hline 7 & $\begin{array}{l}\text { Ismaeel and Zakaria } \\
(2020)\end{array}$ & Interviews & 7 managers & 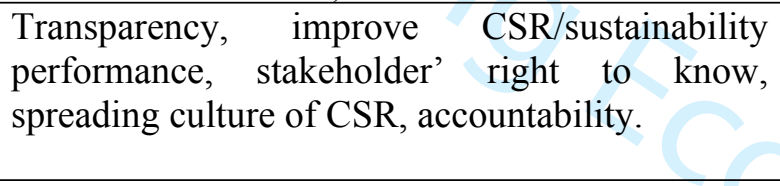 & $\begin{array}{l}\text { Oman, Kuwait, } \\
\text { UAE, Lebanon, } \\
\text { Qatar, Palestine, } \\
\text { Bahrain }\end{array}$ \\
\hline 8 & $\begin{array}{l}\text { Jaggi and Zhao } \\
(1996)\end{array}$ & Questionnaire survey & 28 managers & Improve company image, inform stakeholders & Hong Kong \\
\hline 9 & $\begin{array}{l}\text { Matta, Akhter and } \\
\text { Malarvizhi (2019) }\end{array}$ & Questionnaire survey & 54 companies & $\begin{array}{l}\text { Avoid providing sensitive information, no legal } \\
\text { requirement to report, avoid possible damage to } \\
\text { company's reputation. }\end{array}$ & India \\
\hline
\end{tabular}




\begin{tabular}{|c|c|c|c|c|c|}
\hline 10 & $\begin{array}{l}\text { Mitchell and Hill } \\
\text { (2009) }\end{array}$ & $\begin{array}{l}\text { Structured } \\
\text { Questionnaire } \\
\text { interviews }\end{array}$ & 52 companies & $\begin{array}{l}\text { Not important, too difficult, costs too great, not } \\
\text { enough pressure, no legal requirement. }\end{array}$ & South Africa \\
\hline 11 & $\begin{array}{l}\text { Momin and Parker } \\
\text { (2013) }\end{array}$ & $\begin{array}{l}\text { Semi-structured } \\
\text { interviews }\end{array}$ & $\begin{array}{l}39 \text { senior managers from } \\
\text { seven Bangladesh MNC } \\
\text { subsidiaries }\end{array}$ & $\begin{array}{l}\text { Informal norms and beliefs (certain cultural traits } \\
\text { from Islamic religion do not allow self- } \\
\text { presentation of good deeds), No external demand } \\
\text { for information, lax formal reporting regulation. }\end{array}$ & Bangladesh \\
\hline 12 & $\begin{array}{l}\text { Nwobu, Iyoha and } \\
\text { Owolabi (2018) }\end{array}$ & Questionnaire survey & 54 managers & $\begin{array}{l}\text { Initiation by chief executive officer, employee } \\
\text { training, investors' concern, Central Bank } \\
\text { sustainability banking principles, foreign lenders } \\
\text { pressure, Securities and Exchange Commission } \\
\text { Code of Corporate Governance. }\end{array}$ & Nigeria \\
\hline 13 & Rahaman (2000) & Personal interviews & $\begin{array}{l}28 \text { senior accountants and } \\
\text { managers }\end{array}$ & $\begin{array}{l}\text { Information on environmental issues likely to be } \\
\text { misleading, information does not influence } \\
\text { investment decision, pressure from the World } \\
\text { Bank and the IMF, need to adhere to best } \\
\text { accounting practice, management philosophy and } \\
\text { government regulation. }\end{array}$ & Ghana \\
\hline 14 & Rahaman (2004) & Personal Interviews & $\begin{array}{l}54 \text { individuals including } \\
\text { top management and } \\
\text { operational staff members }\end{array}$ & $\begin{array}{l}\text { Pressure to comply with the requirements of } \\
\text { funding agencies such as the World Bank. }\end{array}$ & Ghana \\
\hline 15 & $\begin{array}{l}\text { Teoh and Thong } \\
\text { (1984) }\end{array}$ & Personal interviews & $\begin{array}{l}100 \text { companies (mostly } \\
\text { chief executive officers) }\end{array}$ & $\begin{array}{l}\text { Annual reports always kept very brief, no reason } \\
\text { to report, information disclosed through other } \\
\text { channels other than the annual report. }\end{array}$ & Malaysia \\
\hline 16 & $\begin{array}{l}\text { Zhao and Patten } \\
(2016)\end{array}$ & Personal interviews & 14 managers & $\begin{array}{l}\text { Peer institutions pressure, image enhancement, } \\
\text { public pressure. }\end{array}$ & China \\
\hline
\end{tabular}




\section{Table 2: GRI's practical actions to increase and improve sustainability reporting in developing countries}

\begin{tabular}{|c|c|c|c|}
\hline & Activities & Practical actions & Achievements/ongoing \\
\hline \multirow[t]{2}{*}{1} & \multirow[t]{2}{*}{$\begin{array}{l}\text { Standards } \\
\text { development }\end{array}$} & $\begin{array}{l}\text { Expand and improve the use } \\
\text { of GRI Standards in } \\
\text { developing countries }\end{array}$ & $\begin{array}{l}\text { Developed and published } 37 \text { sustainability reporting standards, Johannesburg Stock Exchange, } \\
\text { Indonesia Stock Exchange, Securities and Exchange Board in India, Bursa Malaysia and the } \\
\text { Nigerian Stock Exchange now use GRI sustainability reporting standards as a baseline for } \\
\text { businesses to be listed. }\end{array}$ \\
\hline & & $\begin{array}{l}\text { Implement the joint UNGC, } \\
\text { WBCSD and GRI project, the } \\
\text { SDG Compass, which } \\
\text { provides a reporting toolkit } \\
\text { for business to measure their } \\
\text { contribution to the SDGs. }\end{array}$ & $\begin{array}{l}\text { Companies using GRI sustainability standards can now show their contributions to sustainable } \\
\text { development goals (SDGs) by adding a column to their GRI index mapping the relevant GRI } \\
\text { disclosure against the list of relevant SDGs. }\end{array}$ \\
\hline \multirow[t]{2}{*}{2} & \multirow[t]{2}{*}{ Value Chain/SME } & $\begin{array}{l}\text { Build SME reporting in } \\
\text { developing countries }\end{array}$ & $\begin{array}{l}\text { The Competitive Business Program promotes sustainability reporting among SMEs in target } \\
\text { developing countries. The second phase (2016-2020) is being implemented in Colombia, } \\
\text { Ghana, Indonesia, Peru, South Africa and Vietnam. GRI has established local country desks in } \\
\text { the target countries. }\end{array}$ \\
\hline & & $\begin{array}{l}\text { Training and capacity } \\
\text { building for better quality } \\
\text { reporting }\end{array}$ & $\begin{array}{l}\text { GRI offers (1) Certified Training (2) GRI standards exam (3) Tailored workshops which can be } \\
\text { requested by any organisations and these are run by experienced GRI facilitators. }\end{array}$ \\
\hline \multirow[t]{2}{*}{3} & \multirow[t]{2}{*}{$\begin{array}{l}\text { Report } \\
\text { users/beneficiaries }\end{array}$} & $\begin{array}{l}\text { Promote supply chain } \\
\text { transparency }\end{array}$ & $\begin{array}{l}\text { Supply chain e-learning course covering among others: understanding the long and complex } \\
\text { supply chains behind everyday products; why organisations need to take responsibility for their } \\
\text { entire supply chain and the challenges involved; the business case for supply chain sustainability } \\
\text { transparency; current practices in reporting on supply chain. }\end{array}$ \\
\hline & & $\begin{array}{l}\text { Empower users of data: } \\
\text { activate civil society, media, } \\
\text { investors }\end{array}$ & $\begin{array}{l}\text { A research report entitled 'Informing decisions, driving change: The role of data in a } \\
\text { sustainable future' used by GRI to improve reporting standards. }\end{array}$ \\
\hline 4 & $\begin{array}{l}\text { New Indicators and } \\
\text { thematic fields }\end{array}$ & $\begin{array}{l}\text { Develop creative } \\
\text { communications around } \\
\text { GRI's work, and help } \\
\text { corporate actors and reporters } \\
\text { package and communicate } \\
\text { their sustainability } \\
\text { information with stakeholders }\end{array}$ & $\begin{array}{l}\text { The GRI Digital Reporting Platform enables SMEs to collect data about their activities in a } \\
\text { simpler manner and such information can easily be incorporated into sustainability reporting by } \\
\text { larger companies. GRI uses technology to create a platform that contributes to effective } \\
\text { sustainability reporting and activate user communication. }\end{array}$ \\
\hline
\end{tabular}


Table 3:

Sustainability reporting in developing countries 2014-2019*

\begin{tabular}{l|l}
\hline Panel A: AFRICA & Number of organisations uploading their sustainability
\end{tabular}

\begin{tabular}{|c|c|c|c|c|c|c|c|}
\hline Panel A: AFRICA & $\begin{array}{l}\text { reports } \\
\text { databas }\end{array}$ & n the Glo & al Rep & ing Init & ive (G) & abinty & \\
\hline North Africa & 2014 & 2015 & 2016 & 2017 & 2018 & 2019 & $\begin{array}{l}(+/-) \text { over } 6 \\
\text { years }\end{array}$ \\
\hline Algeria & 0 & 0 & 0 & 0 & 0 & 0 & 0 \\
\hline Egypt & 5 & 3 & 5 & 6 & 4 & 6 & 1 \\
\hline Libya & 0 & 0 & 0 & 0 & 0 & 0 & 0 \\
\hline Mauritania & 0 & 0 & 0 & 0 & 0 & 0 & 0 \\
\hline Morocco & 4 & 6 & 8 & 7 & 4 & 10 & 6 \\
\hline Sudan & 0 & 0 & 0 & 0 & 0 & 0 & 0 \\
\hline Tunisia & 0 & 0 & 0 & 0 & 0 & 0 & 0 \\
\hline Central Africa & & & & & & & \\
\hline Cameroon & 0 & 0 & 0 & 1 & 0 & 0 & 0 \\
\hline Central African Republic & 0 & 0 & 0 & 0 & 0 & 0 & 0 \\
\hline Chad & 0 & 0 & 0 & 0 & 0 & 0 & 0 \\
\hline $\begin{array}{l}\text { Congo (Democratic Republic } \\
\text { of) }\end{array}$ & 0 & 0 & 0 & 0 & 0 & 0 & 0 \\
\hline Equatorial Guinea & 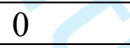 & 0 & 0 & 0 & 0 & 0 & 0 \\
\hline Gabon & 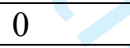 & 0 & 1 & 1 & 0 & 0 & 0 \\
\hline Sao Tome and Principe & 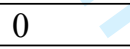 & 0 & 1 & 0 & 1 & 0 & 0 \\
\hline East Africa & & & & & & & \\
\hline Burundi & 0 & 0 & 1 & 1 & 1 & 0 & 0 \\
\hline Comoros & 0 & 0 & 0 & 0 & 0 & 0 & 0 \\
\hline Democratic R. Congo & 0 & 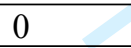 & 0 & 0 & 0 & 0 & 0 \\
\hline Djibouti & 0 & +8 & 0 & 0 & 0 & 0 & 0 \\
\hline Eritrea & 0 & 0 & 0 & 0 & 0 & 0 & 0 \\
\hline Ethiopia & 0 & 1 & 1 & 0 & 1 & 0 & 0 \\
\hline Kenya & 3 & 6 & 25 & 34 & 28 & 1 & -2 \\
\hline Madagascar & 0 & 0 & 1 & 1 & 1 & 0 & 0 \\
\hline Rwanda & 0 & 0 & 1 & 1 & 1 & 0 & 0 \\
\hline Somalia & 0 & 0 & 0 & 0 & 0 & 0 & 0 \\
\hline Uganda & 0 & 0 & 3 & 6 & 5 & 6 & 6 \\
\hline United Republic of Tanzania & 0 & 0 & 2 & 3 & 3 & 0 & 0 \\
\hline
\end{tabular}




\begin{tabular}{|c|c|c|c|c|c|c|c|}
\hline \multirow{2}{*}{$\begin{array}{l}\text { Panel A: AFRICA (cont..) } \\
\text { Southern Africa }\end{array}$} & \multicolumn{7}{|c|}{$\begin{array}{l}\text { Number of organisations uploading their sustainability reports on } \\
\text { Global Reporting Initiative (GRI) database }\end{array}$} \\
\hline & 2014 & 2015 & 2016 & 2017 & 2018 & 2019 & $\begin{array}{l}(+/-) \text { over } 6 \\
\text { years }\end{array}$ \\
\hline Angola & 1 & 2 & 9 & 9 & 5 & 0 & -1 \\
\hline Botswana & 1 & 6 & 12 & 12 & 9 & 0 & -1 \\
\hline Lesotho & 0 & 0 & 0 & 0 & 0 & 0 & 0 \\
\hline Malawi & 0 & 0 & 0 & 0 & 3 & 1 & 1 \\
\hline Mauritius & 5 & 8 & 21 & 17 & 15 & 1 & -4 \\
\hline Mozambique & 0 & 0 & 0 & 0 & 0 & 0 & 0 \\
\hline Namibia & 2 & 3 & 3 & 2 & 4 & 0 & -2 \\
\hline South Africa & 299 & 275 & 281 & 269 & 248 & 200 & -99 \\
\hline Zambia & 0 & 0 & 3 & 4 & 3 & 1 & 1 \\
\hline Zimbabwe & 3 & 4 & 13 & 16 & 13 & 0 & -3 \\
\hline \multicolumn{8}{|l|}{ West Africa } \\
\hline$x^{2}$ & 0 & 0 & 0 & 0 & 0 & 0 & 0 \\
\hline Burkina Faso & 0 & 0 & 2 & 3 & 3 & 0 & 0 \\
\hline Cape Verde & 1 & 1 & 1 & 1 & 0 & 0 & -1 \\
\hline Cote d'Ivoire & 0 & 2 & 6 & 5 & 6 & 0 & 0 \\
\hline Gambia & 0 & 0 & 0 & 0 & 0 & 0 & 0 \\
\hline Ghana & 0 & 0 & 1 & 4 & 13 & 0 & 0 \\
\hline Guinea & 0 & 0 & 1 & 1 & 1 & 0 & 0 \\
\hline Guinea-Bissau & 8 & 0 & 0 & 0 & 0 & 0 & 0 \\
\hline Liberia & 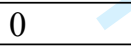 & 0 & 0 & 0 & 0 & 0 & 0 \\
\hline Mali & 0 & 0 & 0 & 0 & 0 & 0 & 0 \\
\hline Niger & 0 & 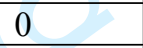 & 0 & 0 & 0 & 0 & 0 \\
\hline Nigeria & 7 & 9 & 25 & 32 & 21 & 4 & -3 \\
\hline Senegal & 0 & 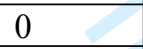 & 1 & 1 & 3 & 0 & 0 \\
\hline Sierra Leone & 0 & 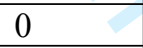 & 0 & 0 & 0 & 0 & 0 \\
\hline Togo & 0 & 0 & 0 & 1 & 1 & 1 & 1 \\
\hline \multicolumn{7}{|c|}{ Net increase(decrease) in number of organisation reporting for the Africa region } & $(100)$ \\
\hline \multicolumn{8}{|c|}{$\begin{array}{l}\text { Number of countries with at least one organisation reporting as at } 31 / 12 / 2019=10 / 51=19.6 \% \\
\text { Number of countries with at least one organisation reporting as at } 31 / 12 / 2019=11 / 51=21.6 \% \\
\text { Net increase in number of countries with at least one organisation reporting }(2014-2019)=(1) \quad(2.0 \%)\end{array}$} \\
\hline
\end{tabular}




\begin{tabular}{|c|c|c|c|c|c|c|c|}
\hline \multirow{2}{*}{$\begin{array}{l}\text { Panel B: ASIA } \\
\text { East Asia }\end{array}$} & \multicolumn{7}{|c|}{$\begin{array}{l}\text { Number of organisations uploading their sustainability reports on the } \\
\text { Global Reporting Initiative (GRI) database }\end{array}$} \\
\hline & 2014 & 2015 & 2016 & 2017 & 2018 & 2019 & $\begin{array}{l}(+/-) \text { over } 6 \\
\text { years }\end{array}$ \\
\hline Brunei Darussalam & 0 & 0 & 0 & 0 & 0 & 0 & 0 \\
\hline Mainland China & 354 & 397 & 679 & 872 & 915 & 604 & 250 \\
\hline Hong Kong SAR & 70 & 81 & 98 & 215 & 190 & 76 & 6 \\
\hline Indonesia & 68 & 95 & 81 & 96 & 104 & 12 & -56 \\
\hline Malaysia & 33 & 41 & 43 & 59 & 93 & 54 & 21 \\
\hline Myanmar & 0 & 0 & 0 & 1 & 1 & 0 & 0 \\
\hline Papua New Guinea & 2 & 2 & 1 & 2 & 2 & 1 & -1 \\
\hline Philippines & 28 & 28 & 32 & 33 & 35 & 22 & -6 \\
\hline Republic of Korea & 115 & 87 & 81 & 67 & 51 & 66 & -49 \\
\hline Singapore & 36 & 40 & 45 & 71 & 104 & 61 & 25 \\
\hline Taiwan Province of China & 209 & 408 & 455 & 494 & 479 & 505 & 296 \\
\hline Thailand & 41 & 42 & 107 & 117 & 129 & 126 & 85 \\
\hline Viet Nam & 16 & 28 & 41 & 59 & 70 & 45 & 29 \\
\hline \multicolumn{8}{|l|}{ South Asia } \\
\hline Bangladesh & 17 & 26 & 27 & 36 & 35 & 4 & -13 \\
\hline India & 36 & 104 & 147 & 315 & 64 & 47 & 11 \\
\hline Iran (Islamic Republic Of) & 0 & 0 & 0 & 2 & 2 & 1 & 1 \\
\hline Nepal & 0 & 0 & 0 & 0 & 0 & 0 & 0 \\
\hline Pakistan & 10 & 9 & 9 & 9 & 6 & 4 & -6 \\
\hline Sri Lanka & 52 & 62 & 69 & 104 & 125 & 95 & 43 \\
\hline \multicolumn{8}{|l|}{ Western Asia } \\
\hline Bahrain & 8 & 1 & 1 & 1 & 2 & 2 & 1 \\
\hline Iraq & 0 & 0 & 0 & 0 & 0 & 0 & 0 \\
\hline Israel & 28 & 23 & 27 & 24 & 17 & 10 & -18 \\
\hline Jordan & 5 & 5 & 6 & 5 & 3 & 2 & -3 \\
\hline Kuwait & 7 & 5 & 7 & 2 & 5 & 2 & -5 \\
\hline Lebanon & 1 & 3 & 2 & 2 & 3 & 4 & 3 \\
\hline Oman & 6 & 5 & 6 & 3 & 2 & 2 & -4 \\
\hline Qatar & 23 & 17 & 15 & 15 & 2 & 1 & -22 \\
\hline Saudi Arabia & 13 & 9 & 9 & 9 & 3 & 7 & -6 \\
\hline Syrian Arab Republic & 0 & 0 & 0 & 0 & 0 & 0 & 0 \\
\hline Turkey & 61 & 59 & 80 & 51 & 27 & 25 & -36 \\
\hline United Arab Emirates & 38 & 41 & 40 & 26 & 23 & 21 & -17 \\
\hline Yemen & 0 & 0 & 0 & 0 & 1 & 0 & 0 \\
\hline \multicolumn{7}{|c|}{ Total increase(decrease) for the Asian region } & 531 \\
\hline
\end{tabular}




\begin{tabular}{|c|c|c|c|c|c|c|c|}
\hline \multirow{2}{*}{$\begin{array}{l}\text { Panel C: LATIN AMERICA } \\
\text { AND THE CARIBBEAN } \\
\text { Caribbean }\end{array}$} & \multicolumn{7}{|c|}{$\begin{array}{l}\text { Number of organisations uploading their sustainability reports on the } \\
\text { Global Reporting Initiative (GRI) database }\end{array}$} \\
\hline & 2014 & 2015 & 2016 & 2017 & 2018 & 2019 & $\begin{array}{l}(+/-) \text { over } 6 \\
\text { years }\end{array}$ \\
\hline Barbados & 0 & 0 & 0 & 0 & 0 & 0 & 0 \\
\hline Cuba & 0 & 0 & 0 & 0 & 0 & 0 & 0 \\
\hline Dominican Republic & 3 & 3 & 3 & 3 & 0 & 2 & -1 \\
\hline Guyana & 0 & 0 & 0 & 0 & 0 & 0 & 0 \\
\hline Haiti & 0 & 0 & 0 & 0 & 0 & 0 & 0 \\
\hline Jamaica & 0 & 0 & 0 & 0 & 0 & 0 & 0 \\
\hline Trinidad and Tobago & 0 & 0 & 0 & 0 & 0 & 0 & 0 \\
\hline \multicolumn{8}{|l|}{ Mexico and Central America } \\
\hline Costa Rica & 6 & 8 & 5 & 11 & 14 & 17 & 11 \\
\hline El Salvador & 2 & 2 & 4 & 7 & 0 & 0 & -2 \\
\hline Guatemala & 0 & 0 & 1 & 3 & 5 & 4 & 4 \\
\hline Honduras & 2 & 6 & 2 & 5 & 3 & 8 & 6 \\
\hline Mexico & 94 & 114 & 104 & 96 & 102 & 75 & -19 \\
\hline Nicaragua & 0 & 0 & 1 & 0 & 1 & 1 & 1 \\
\hline Panama & 5 & 4 & 5 & 8 & 6 & 4 & -1 \\
\hline \multicolumn{8}{|l|}{ South America } \\
\hline Argentina & 85 & 102 & 96 & 104 & 92 & 129 & 44 \\
\hline Bolivia (Plurinational State of) & 8 & 11 & 18 & 19 & 16 & 9 & 1 \\
\hline Brazil & 256 & 270 & 253 & 251 & 151 & 196 & -60 \\
\hline Chile & 57 & 68 & 71 & 69 & 58 & 24 & -33 \\
\hline Colombia & 174 & 202 & 197 & 189 & 166 & 112 & -62 \\
\hline Ecuador & 20 & 26 & 26 & 29 & 23 & 18 & -2 \\
\hline Paraguay & 1 & 2 & 3 & 3 & 3 & 4 & 3 \\
\hline Peru & 45 & 69 & 64 & 72 & 166 & 269 & 224 \\
\hline Uruguay & 11 & 19 & 16 & 16 & 15 & 8 & -3 \\
\hline $\begin{array}{l}\text { Venezuela (Bolivarian } \\
\text { Republic of) }\end{array}$ & 3 & 4 & 5 & 4 & 3 & 1 & -2 \\
\hline \multicolumn{6}{|c|}{ Net increase (decrease) for the Latin America and the Caribbean region } & & 107 \\
\hline \multicolumn{8}{|c|}{$\begin{array}{l}\text { Number of countries with at least one organisation reporting as at } 31 / 12 / 2019=17 / 24=70.8 \% \\
\text { Number of countries with at least one organisation reporting as at } 31 / 12 / 2019=16 / 24=66.7 \% \\
\text { Net increase in number of countries with at least one organisation reporting }(2014-2019)=1=4.1 \%\end{array}$} \\
\hline
\end{tabular}

*The source for the information presented in this table is the GRI database

(https://database.globalreporting.org). GRI notes that 'As the information for the last 2 reporting years is incomplete due to ongoing data collection and the Standards Report Registration process, the search on the report year filter is disabled for the years 2018 and 2019. The change was done to avoid any data or trend misinterpretations. However, we are still collecting and showing on this Database reports published for these 2 years - these reports can be found using the other available filters'. To obtain the information for the years 2018 and 2019 we searched the database for all reports and then counted those uploaded during each of these two calendar years. 


\begin{tabular}{|c|c|c|c|c|c|c|c|c|}
\hline \multirow{2}{*}{\multicolumn{3}{|c|}{ 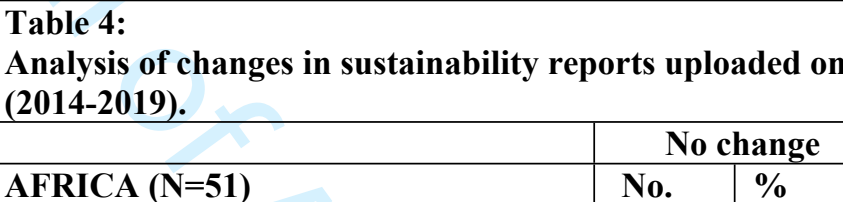 }} & \multicolumn{2}{|c|}{ Decrease } & \multicolumn{2}{|c|}{ Increase } & \multicolumn{2}{|c|}{ Total } \\
\hline & & & No. & $\%$ & No. & $\%$ & & \\
\hline North Africa (7) & 5 & 71.43 & 0 & 0 & 2 & 28.57 & 7 & 100 \\
\hline Central Africa (7) & 7 & 100 & 0 & 0 & 0 & 0 & 7 & 100 \\
\hline East Africa (12) & 10 & 83.34 & 1 & 8.33 & 1 & 8.33 & 12 & 100 \\
\hline Southern Africa(10) & 2 & 20.00 & 6 & 60.00 & 2 & 20.00 & 10 & 100 \\
\hline West Africa(15) & $\underline{12}$ & $\underline{80.00}$ & $\underline{2}$ & $\underline{13.33}$ & $\underline{1}$ & 6.67 & $\underline{15}$ & $\underline{100}$ \\
\hline Total & 36 & 70.59 & 9 & 17.65 & 6 & 11.76 & 51 & 100 \\
\hline 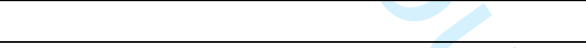 & & & & & & & & \\
\hline ASIA (N=32) & & & & & & & & \\
\hline East Asia (13) & 2 & 15.38 & 4 & 30.77 & 7 & 53.85 & 13 & 100 \\
\hline South Asia (6) & 1 & 16.67 & 2 & 33.33 & 3 & 50.00 & 6 & 100 \\
\hline Western Asia (13) & $\underline{3}$ & 23.08 & $\underline{8}$ & 61.54 & $\underline{2}$ & $\underline{15.38}$ & $\underline{13}$ & $\underline{100}$ \\
\hline Total & 6 & 18.75 & 14 & 43.75 & 12 & 37.50 & 32 & 100 \\
\hline $\begin{array}{l}\text { LATIN AMERICA AMD } \\
\text { CARIBBEAN (N=24) }\end{array}$ & & & & & & & & \\
\hline Caribbean (7) & 6 & 85.71 & 1 & 14.29 & 0 & 0.00 & 7 & 100 \\
\hline Mexico and Central America(7) & 0 & 0.00 & 3 & 42.86 & 4 & 57.14 & 7 & 100 \\
\hline South America(10) & $\underline{0}$ & $\underline{0.00}$ & $\underline{6}$ & 60.00 & $\underline{4}$ & $\underline{40.00}$ & $\underline{10}$ & $\underline{100}$ \\
\hline Total & $\overline{6}$ & 25.00 & 10 & 41.66 & 8 & 33.33 & 24 & 100 \\
\hline
\end{tabular}

